\title{
OPTIMIZING BALANCE SHEET FOR BANKS IN INDIA USING GOAL PROGRAMMING
}

\author{
Jyoti Tanwar \\ Senior Research Scholar \\ Department of Economics and Finance \\ BITS-Pilani, Pilani Campus \\ Jhunjunu, Rajasthan- 333031, India \\ E-mail: jyotanwar@gmail.com \\ Arun Kumar Vaish \\ Assistant Professor \\ Department of Economics and Finance \\ BITS- Pilani, Pilani Campus, India \\ E-mail: akvaish@pilani.bits-pilani.ac.in \\ NVM Rao \\ Professor \\ Department of Economics and Finance \\ BITS-Pilani, Pilani Campus, India \\ E-mail:nvmrao@pilani.bits-pilani.ac.in
}

\begin{abstract}
In earlier years, there was abundance of funds in banks in the form of demand and savings deposits. Hence, the focus of banks was mainly on asset management. But intense competition and volatility of interest rate due to banking reforms reduced the availability of low-cost funds and therefore, banks focused on liability management as well. These pressures call for structured and comprehensive measures and not just ad hoc action. This is how banks started to concentrate more on the management of both sides of the balance sheet. As a result, the concept of asset-liability management originated in India and introduced in the Indian banking industry since 1st April 1999 to administer the risk management aspects. This paper attempts to optimize assets and liabilities of banks using goal programming technique. Secondary data is collected from annual reports of Allahabad bank from 2010-2019 and RBI website is used for modelling. The findings show that in Allahabad bank, goal programming help in achieving optimization and increase profitability. The model incorporating constraints and set objectives. It model can support banks in decision making process, planning, budgeting, and forecasting. An attempt is made to use realistic goals and constraints after discussing with bank officials.
\end{abstract}

Keywords: Asset-Liability Management, Risk Management, Goal Programming, Banking.

JEL Classification Codes: C61, G21, G32. 


\section{INTRODUCTION}

Post liberalization, funds were abundant in banks in the form of demand and savings deposits. Due to the availability of funds, the focus of banks was mainly on asset management. But intense competition and volatility of interest rate due to banking reforms reduced the availability of low-cost funds, and therefore, banks focused on liability management as well (Chaturvedi, 2014). These pressures call for structured and comprehensive measures and not just ad hoc action. That is how banks started to concentrate more on the management of both sides of the balance sheet. As a result, the concept of asset-liability management originated in India and was introduced in the Indian banking industry on 1st April 1999 to administer the risk management aspects (RBI, 1999).

Asset-liability management is a comprehensive and dynamic framework that mainly focuses on measuring, monitoring, and managing the market risk of a bank (Joshi \& Sontakay, 2017). The Society of Actuaries Task Force on ALM Principles, Canada, defines ALM as "Asset liability Management is the on-going process of formulating, implementing, monitoring, and revising strategies related to assets and liabilities in an attempt to achieve financial objectives for a given set of risk tolerances and constraints." ("Professional Actuarial Specialty Guide: Asset- Liability Management," 2003). The primary function of asset-liability management is to manage the liquidity risk, market risk, creating risk management, funding, capital planning, and profit planning with growth projection (Matz \& Neu, 2007).

Asset-liability management is a process that facilitates an institution to manage its balance sheet by allowing changes in the interest-rate-sensitive assets and liabilities and liquidity scenario. Assetliability management provides volatility, product innovation and ensures regulatory and government practices with management (Kalyan, 2017). The objective of ALM is to manage risk and not to eliminate risk. In finance, risk and rewards go hand in hand (Adebisi et al., 2020; Haddad et al., 2019; Riyazahmed \& Baranwal, 2021).

This research paper deals with the optimization of banks' assets and liabilities in India using the example of the Allahabad bank. The methodology used in this research paper is based on Analytical Hierarchy Process (AHP) for assigning weights to goals, and later weighted goal programming is applied to optimize the assets and liabilities while simultaneously fulfilling the statutory and regulatory compliance. In goal programming, the target is to fulfil the most critical goals and determine the deviation from the goals. The same concept is used to obtain an asset-liability mix for Allahabad bank.

\section{REVIEW OF LITERATURE}

Asset-liability management is termed to be a process that facilitates an institution to manage its balance sheet by allowing changes in the interest-rate-sensitive assets and liabilities and liquidity scenario. Asset-liability management provides volatility, product innovation and ensures regulatory and government practices with management recognition (Singh \& Tandon, 2012; Greuning \& Bratanovic, 2009). Asset-liability management is considered an appropriate strategy for finance companies, leasing companies, insurance companies, and others as it helps in managing financial and management risk. It not only includes formalization and understanding of various risks but also identifies the way to quantify and manage those risks. The understanding of the ALM concept can help in reducing risk and improving the financial soundness of financial institutions (Fabozzi \& Konishi, 1991). The soundness and effectiveness of a banking system are often measured by efficiency, profitability improvement, and increasing volume of funds flowing from savers to borrowers, etc. (Tanwar et al., 2020). The process of asset-liability management is based on three pillars:

- ALM Organization: It mainly includes the structure and responsibilities of members of the Asset Liability Management Committee. ALCO makes decisions relating to balance sheet 
planning while incorporating the risk-return perspective and management of interest risk and liquidity risk.

- ALM Information system: It mainly includes the collection of information accurately, information availability, and accuracy adequacy.

- ALM Process: The third pillar defines the process of asset-liability management that mainly includes the parameter of risk identification, risk measurement, risk management, and managing policies with tolerance level as per the guidelines given by the Reserve Bank of India (Chaturvedi, 2014; Jayanthi \& Umarani, 2014; Joshi \& Sontakay, 2017; Singh, 2013).

The objective of ALM is to manage risk and not to eliminate risk. In finance, risk and rewards go hand in hand. ALM attempts to increase profitability while managing risk on the asset and liability sides of the balance sheet. ALM is a technique that helps banks and other financial institutions to limit risk and increase profits. Various deterministic models, stochastic models, and linear programming models have been developed by scholars to mitigate risk and increase profits (Chambers \& Charnes, 1961; Cohen \& Hammer, 1967; Dash \& Pathak, 2011; Eatman \& Sealey, 1979; Fielitz \& Loeffler, 1979; Kosmidou \& Zopounidis, 2002, 2004a, 2004b). Various research papers have used goal programming in ALM to optimize balance sheets, deploy funds, and allocate assets, etc. (Giokas \& Vassiloglou, 1991; Naderi et al., 2013; Viswanathan et al., 2014).

Goal Programming is a widely used technique in the field of multi-criteria decision making, where multiple constraints and goals can be incorporated by the decision-maker (Chakroun \& Abid, 2013; Zaloom et al., 1986). Goal Programming technique is a mathematical technique used in operation research for generating an optimized solution for multiple goals. Real-world businesses, households, financial institutions, and Non-profit organizations, etc., deal with various problems at a time and not just one. They need a solution that satisfies all the targets and goals. Goal Programming (GP) is a mathematical model that helps provides a solution to multiple objectives. The Goal Programming technique was first used by Chambers and Charnes (1961) in finance and accounting, and later, many other authors used the technique in portfolio selection, asset management, marketing, capital structure, budgeting, planning, and banking, etc. The GP technique, as mentioned, assists management in the planning process by providing a meaningful framework; however, it does not eliminate the decisionmaking function of management.

In this model, many objectives can be achieved while seeking an optimal and feasible solution. In this model, goal constraints are set equal to target values that need not be achieved. The model helps to determine the extent to which each objective can be fulfilled. It may not be possible to achieve all the goals at once. Therefore, the model generates a solution that shows the deviation from the target and tries to satisfy the most important objectives is based on ranking/priority. In developing future plans, bank management set targets and goals to be achieved. These goals can be the maximization of profits, minimization of risk, increasing the share of the market, maintaining sufficient liquidity or balanced portfolio subject to legal requirements imposed by the Reserve Bank of India and other management constraints. The GP model delivers the most optimum solution for such complex problems to assist bank management in a more efficient planning process (Tanwar et al., 2020).

Zaloom et al. (1986) studied capital and liquidity planning in bank asset management with the implication of goal programming. Giokas and Vassiloglou (1991), in their study, used multi-objective programming for assets and liabilities management in the area of banking. They asserted that banks have to deal with multiple objectives all the time. Management of the bank has the responsibility to increase profitability as well as concern for risk mitigation. In order to maximize revenue/profit, banks have to increase their market share of both deposits and credits. Since a linear programming model can 
deal with a single objective function at a time, goal programming is a much appropriate technique for multiple goals. Viswanathan and Balasubramanian (2007) applied the pre-emptive GP model to deploy funds optimally within various asset classes having varied risk and return characteristics. While gaols are satisfied, regulatory and other banking constraints are also fulfilled. Jain et al. (2010) presented the ALM model for pensioners to manage the risk of volatility on investment returns and liabilities. Kruger (2011) used a single-period approach and multi-period approach to finds that it is possible to optimize the balance sheet using advanced software. Sedzro et al. (2012) optimized asset allocation based on investor's risk profile and economic scenarios with the help of goal programming.

Viswanathan et al. (2014) also applied the goal programming model to optimally allocate the assets to achieve goals such as non-interest Income, Deposits, Investments in SLR and non- SLR securities, and Advances. Halim et al. (2015), in their study, determined the use of the GP model to attain various goals of the bank in Malaysia. The model proposed in the study supports financial decision-making in diverse economic scenarios. Likewise, Fortson and Dince (1977) developed a model for a country bank using Goal Programming, where the model incorporated profitability, capital adequacy, liquidity, and credit-deposit ratio as multiple goals to be achieved. The model benefited the management by setting goals under different scenarios.

Chakroun and Abid (2013) presented ALM to help Tunisian commercial banks to develop a long-term strategy using their balance sheet. The GP tool has been used to optimize the solution for maximizing net interest margin, solvency, improving liquidity, and credit-deposit ratio under the given structural, political, and regulatory constraints. The results of the model outperform the present strategy applied by banks and open scope for improvement.

Goal Programming assists in structured decision-making; however, it has no method of evaluating the priority in goals or assigning weights to goals. As businesses have limited resources, it is difficult to fulfill all the goals. Therefore, it is essential to rank or weight goals so that the most important goals are satisfied before approaching the least important goal. In such a scenario, Analytical Hierarchy Process is a useful tool to determine ranks/weights for the goals. Analytical Hierarchy Process (AHP) allows pair-wise comparison and shows the domination of one element concerning others. AHP reckon the judgment of experts to obtain priority scales. The AHP is first introduced by Saaty (2008) as the most common multi-criteria decision-making method.

\section{OBJECTIVE OF THE STUDY}

There are very few studies in the Indian banking industry that have extensively applied goal programming for asset and liability management. This study uses AHP to determine the weights/rank to be used in Goal Programming in the Indian banking scenario. In the Indian banking industry, the use of GP and AHP to optimize Asset-Liability Management is very limited. Based on the above literature, the current study tries to assess the optimal structure of assets and liabilities in the balance sheet based on set goals and constraints. The policy implications for the banks will be determined, and the flexibility of the model will be ascertained.

Commercial banks in India have to follow the guidelines and regulations issued by the Reserve Bank of India from time to time. At present, RBI has issued guidelines related to maintenance of Cash Reserve Ratio (CRR), Statutory Liquidity Ratio (SLR), Priority Sector Lending (PSL), Capital adequacy ratio, and liquidity coverage ratio, etc. The model will incorporate all such restrictions in an objective setting. 


\section{METHODOLOGY}

The main objective of this paper is to design a mathematical model that can optimize the assets and liabilities of the banks in India using Goal Programming. In this research paper, the case study of Allahabad bank is taken to reflect the implications of the model. The relative importance of the goals of Indian scheduled commercial banks is determined with AHP. The data is obtained from annual reports of Allahabad banks over the last ten years, i.e., from 2010 to 2019, from its website. Secondary data has also been collected from the Reserve Bank of India website with respect to constraints and norms to be followed by banks. Goal Programming is used for solving the asset-liability management problem with the help of LINGO version 17 software.

The goals and weights have been determined using the AHP questionnaire. After the analysis, the following goals for the banks are suggested by 13 experts - liquidity risk, Capital Adequacy, Market share of the deposit, Market share of Credit, Return on Asset, Return on Equity, and reducing NonPerforming Assets.

Table 1. Weights of Goal as per AHP

\begin{tabular}{|l|l|}
\hline Goals & Weights (using AHP) \\
\hline Market share of credit & 0.038 \\
\hline Market share of deposits & 0.035 \\
\hline Return on assets & 0.119 \\
\hline Return on equity & 0.116 \\
\hline Capital adequacy ratio & 0.244 \\
\hline Liquidity risk & 0.284 \\
\hline Non-Performing Asset & 0.101 \\
\hline
\end{tabular}

\section{Goal Programming}

Ignizio (1981) developed the following steps to formulate the GP model:

- Define the decision variables

- Define the structural constraints and goal constraints

- Determine the relative weight

- Define the objective function

- State the non-negative requirement

The structural constraints are the statutory constraints and management constraints in the bank for the assets and liabilities. Goal constraints are the target to be achieved with positive and negative deviations (Tanwar et al., 2020). The objective function in the GP model is to minimize the variations. In this paper, weighted goal programming is used where the objective is to minimize the weighted sum of goal deviations. The weighted Goal Programming as given by Charnes \& Cooper (1977) is given below:

Minimize

$$
z=\sum_{i=1}^{m}\left(w_{i}^{-} d_{i}^{-}+w_{i}^{+} d_{i}^{+}\right)
$$

Subject to linear constraints- 
Goal Constraints:

Structural constraints:

$$
\sum_{j=1}^{n} a_{i j} x_{j}+d_{i}^{-}-d_{i}^{+}=b_{i} \quad, \quad i=1,2, \ldots, m
$$

With

$$
\sum_{j=1}^{n} a_{i j} x_{j}\left[\begin{array}{l}
\leq \\
= \\
\geq
\end{array}\right] b_{i}, \quad i=m+1, \ldots, m+p
$$

$x_{i}, d_{i}^{-}, d_{i}^{+} \geq 0 \quad, i=1,2, \ldots, m \quad, \quad j=1,2, \ldots, n$

Where $\mathrm{m}, \mathrm{p}$, and $\mathrm{n}$ represent goals, structural constraints, and decision variables, respectively.

$\mathrm{W}_{\mathrm{i}}$ negative represents weight assigned to negative deviation and $\mathrm{W}_{\mathrm{i}}$ positive represent weight assigned to positive deviations.

$D_{i}$ negative represents the negative deviational variable of the $i^{\text {th }}$ goal (underachievement of goal).

$D_{i}$ positive represents the positive deviational variable of the $i^{\text {th }}$ constraints (overachievement of goal).

$\mathrm{B}_{\mathrm{i}}$ represents the aspiration level or the target value.

$\mathrm{Z}=$ objective function

$\mathrm{A}_{\mathrm{ij}}=$ The coefficient associated with variable $\mathrm{j}$ in the $\mathrm{i}^{\text {th }}$ goal

$\mathrm{X}_{\mathrm{j}}=$ the $\mathrm{j}^{\text {th }}$ decision variables

\section{Decision Variables}

Identification of the decision variables:

The Indian bank balance sheet has assets and liabilities. These assets and liabilities are the decision variables.

Assets

Cash and Bank Balance

$\mathrm{YA}_{1}=$ Cash in hand

$\mathrm{YA}_{2}=$ Balance with RBI

$\mathrm{YA}_{3}=$ Balance with Banks \& Money at call \& short notice in India

$\mathrm{YA}_{4}=$ Balance with Banks \& Money at call \& short notice outside India

\section{Investments}

$\mathrm{YA}_{5}=$ Investment in government securities

$\mathrm{YA}_{6}=$ Investment in approved securities

$\mathrm{YA}_{7}=$ Shares

$\mathrm{YA}_{8}=$ Debentures

$\mathrm{YA}_{9}=$ Investment in Subsidiaries/Joint Ventures

$\mathrm{YA}_{10}=$ Others (Commercial papers, Mutual funds, etc.)

\section{Advances}

$\mathrm{YA}_{11}=$ Bills Purchased \& discounted

$\mathrm{YA}_{12}=$ Cash Credit, Overdrafts, Loans repayable on demand

$\mathrm{YA}_{13}=$ Term Loans

$\mathrm{YA}_{14}=$ Advances in Priority Sector 
$\mathrm{YA}_{15}=$ Advances in Banks in India

$\mathrm{FA}=$ Fixed Assets and Intangible assets

$\mathrm{OA}=$ Other Assets

\section{Liabilities}

Shareholders fund

$\mathrm{XL}_{1}=$ Capital

$\mathrm{XL}_{2}=$ Reserves \& Surplus

\section{Deposits}

$\mathrm{XL}_{3}=$ Demand Deposit

$\mathrm{XL}_{4}=$ Saving Deposits

$\mathrm{XL}_{5}=$ Term Deposits

\section{Borrowings}

Borrowings from India

$\mathrm{XL}_{6}=$ Borrowings from RBI

$\mathrm{XL}_{7}=$ Borrowings from Banks And other institutions \& Agencies

\section{Borrowings outside India}

$\mathrm{XL}_{8}=$ Borrowings outside India

$\mathrm{XL}_{9}=$ Other Liabilities

$\mathrm{XL}_{10}=$ Others (including provisions)

Table 2. Deviations in goals

\begin{tabular}{|l|l|l|}
\hline Goals & Positive deviation & Negative deviation \\
\hline Market Share of Credit & $\mathrm{D}^{+}{ }_{1}$ & $\mathrm{D}_{1}^{-}$ \\
\hline Market Share of Deposit & $\mathrm{D}^{+}{ }_{2}$ & $\mathrm{D}_{2}^{-}$ \\
\hline Return on Asset & $\mathrm{D}_{3}^{+}$ & $\mathrm{D}_{3}^{-}$ \\
\hline Return on Equity & $\mathrm{D}^{+}{ }_{4}$ & $\mathrm{D}_{4}^{-}$ \\
\hline Capital Adequacy & $\mathrm{D}_{5}^{+}$ & $\mathrm{D}_{5}^{-}$ \\
\hline Liquidity Risk & $\mathrm{D}_{6}^{+}$ & $\mathrm{D}_{6}^{-}$ \\
\hline Non-Performing Asset & $\mathrm{D}^{+}$ & $\mathrm{D}_{7}^{-}$ \\
\hline
\end{tabular}

\section{Constraints}

The constraints are an important part of goal programming. Banks follow the guidelines laid down by the Reserve bank of India from time to time. These regulations become constraints for banks in the free flow of work. Here, constraints are divided into two sections. There are system constraints and goal constraints. The constraints are given below for the years 2019:

\section{System or structural constraints}

1. Total Assets $=$ Total Liabilities

$$
\sum_{\mathrm{i}=1}^{13} \mathrm{YA}_{\mathrm{i}}+\mathrm{FA}+\mathrm{OA}=\Sigma_{\mathrm{j}=1} \mathrm{XL}_{\mathrm{j}}
$$


2. Cash Reserve Ratio $=4 \%$

$\mathrm{YA}_{2} \geq 4 \% *$ (Net demand and Time Liability)

$\mathrm{YA}_{2} \geq 4 \% *\left(\mathrm{XL}_{3}+\mathrm{XL}_{4}+\mathrm{XL}_{5}+\mathrm{XL}_{6}+\mathrm{XL}_{7}+\mathrm{XL}_{9}-\mathrm{YA}_{3}-\mathrm{YA}_{15}\right)$

3. Statutory Liquidity Ratio $=19.5 \%$

Liquid Asset $=$ excess cash and balance with RBI over CRR + investment in govt. securities + Investment in approved securities

Liquid Assets $(\mathrm{LA})=\mathrm{YA}_{1}+\left(\mathrm{YA}_{2}\right)-0.04\left(\mathrm{XL}_{3}+\mathrm{XL}_{4}+\mathrm{XL}_{5}+\mathrm{XL}_{6}+\mathrm{XL}_{7}+\mathrm{XL}-\mathrm{YA}_{3}-\mathrm{YA}_{15}\right)+$ $\left(\mathrm{YA}_{3}+\mathrm{YA}_{5}+\mathrm{YA}_{6}\right.$

$\mathrm{NTDL}=\mathrm{XL}_{3}+\mathrm{XL}_{4}+\mathrm{XL}_{5}+\mathrm{XL}_{6}+\mathrm{XL}_{7}+\mathrm{XL}_{9}-\mathrm{YA}_{3}-\mathrm{YA}_{15}$

Therefore, SLR equation is:

$\mathrm{YA}_{1}+\left(\mathrm{YA}_{2}\right)-0.04\left(\mathrm{XL}_{3}+\mathrm{XL}_{4}+\mathrm{XL}_{5}+\mathrm{XL}_{6}+\mathrm{XL}_{7}+\mathrm{XL}_{9}-\mathrm{YA}_{3}-\mathrm{YA}_{15}\right)+\left(\mathrm{YA}_{3}+\mathrm{YA}_{5}+\mathrm{YA}_{6} \geq\right.$ $19.5 \%\left(\mathrm{XL}_{3}+\mathrm{XL}_{4}+\mathrm{XL}_{5}+\mathrm{XL}_{6}+\mathrm{XL}_{7}+\mathrm{XL}_{9}-\mathrm{YA}_{3}-\mathrm{YA}_{15}\right)$

4. Priority Sector Lending $=40 \%$ of the Adjusted Net Banking Credit

$\mathrm{YA}_{14} \geq 40 \%\left(\mathrm{YA}_{11}+\mathrm{YA}_{12}+\mathrm{YA}_{13}\right)$

5. Investments

$$
\begin{aligned}
& \%\left(\sum_{\mathrm{i}=1}^{13} \mathrm{YA}_{\mathrm{i}}+\mathrm{FA}+\mathrm{OA}\right) \leq\left(\mathrm{YA}_{5}+\mathrm{YA}_{6}+\mathrm{YA}_{7}+\mathrm{YA}_{8}+\mathrm{YA}_{9}+\mathrm{YA}_{10}\right) \\
& 26 \%\left(\sum_{\mathrm{i}=1}^{13} \mathrm{YA}_{\mathrm{i}}+\mathrm{FA}+\mathrm{OA}\right) \mathrm{TA}<=\left(\mathrm{YA}_{5}+\mathrm{YA}_{6}+\mathrm{YA}_{7}+\mathrm{YA}_{8}+\mathrm{YA}_{9}+\mathrm{YA}_{10}\right)
\end{aligned}
$$

6. Investments in Government Securities \& approved securities

$\%\left(\mathrm{YA}_{5}+\mathrm{YA}_{6}+\mathrm{YA}_{7}+\mathrm{YA}_{8}+\mathrm{YA}_{9}+\mathrm{YA}_{10}\right) \leq\left(\mathrm{YA}_{5}+\mathrm{YA}_{6}\right)$

$84 \% *\left(\mathrm{YA}_{5}+\mathrm{YA}_{6}+\mathrm{YA}_{7}+\mathrm{YA}_{8}+\mathrm{YA}_{9}+\mathrm{YA}_{10}\right) \leq\left(\mathrm{YA}_{5}+\mathrm{YA}_{6}\right)$

7. Investments in Non-SLR securities

$\%\left(\mathrm{YA}_{5}+\mathrm{YA}_{6}+\mathrm{YA}_{7}+\mathrm{YA}_{8}+\mathrm{YA}_{9}+\mathrm{YA}_{10}\right) \leq\left(\mathrm{YA}_{7}+\mathrm{YA}_{8}+\mathrm{YA}_{9}+\mathrm{YA}_{10}\right)$

$16 \% *\left(\mathrm{YA}_{5}+\mathrm{YA}_{6}+\mathrm{YA}_{7}+\mathrm{YA}_{8}+\mathrm{YA}_{9}+\mathrm{YA}_{10}\right) \leq\left(\mathrm{YA}_{7}+\mathrm{YA}_{8}+\mathrm{YA}_{9}+\mathrm{YA}_{10}\right)$

8. Cash \& Balance with RBI

$$
\begin{aligned}
& \%\left(\sum_{\mathrm{i}=1}^{13} \mathrm{YA}_{\mathrm{i}}+\mathrm{FA}+\mathrm{OA}\right) \leq\left(\mathrm{YA}_{1}+\mathrm{YA}_{2}\right) \\
& 4.5 \% *\left(\sum_{\mathrm{i}=1} \mathrm{YA}_{\mathrm{i}}+\mathrm{FA}+\mathrm{OA}\right) \leq\left(\mathrm{YA}_{1}+\mathrm{YA}_{2}\right)
\end{aligned}
$$

9. Balance with Banks \& Money at call \& short notice in India

$$
\begin{aligned}
& \%\left(\sum_{\mathrm{i}=1} \mathrm{YA}_{\mathrm{i}}+\mathrm{FA}+\mathrm{OA}\right) \geq\left(\mathrm{YA}_{3}\right) \\
& 6.5 \%\left(\sum_{\mathrm{i}=1} \mathrm{YA}_{\mathrm{i}}+\mathrm{FA}+\mathrm{OA}\right) \geq\left(\mathrm{YA}_{3}\right)
\end{aligned}
$$

10. Balance with Banks \& Money at call \& short notice outside India 


$$
\begin{aligned}
& 13 \\
& \%\left(\sum_{\mathrm{i}=1} \mathrm{YA}_{\mathrm{i}}+\mathrm{FA}+\mathrm{OA}\right) \geq\left(\mathrm{YA}_{4}\right) \\
& 13 \\
& 2.8 \%\left(\sum_{\mathrm{i}=1} \mathrm{YA}_{\mathrm{i}}+\mathrm{FA}+\mathrm{OA}\right) \geq\left(\mathrm{YA}_{4}\right)
\end{aligned}
$$

11. Advances

$$
\begin{aligned}
& \stackrel{13}{\%}\left(\sum_{\mathrm{i}=1} \mathrm{YA}_{\mathrm{i}}+\mathrm{FA}+\mathrm{OA}\right) \leq\left(\mathrm{YA}_{11}+\mathrm{YA}_{12}+\mathrm{YA}_{13}\right) \leq \%\left(\sum_{\mathrm{i}=1} \mathrm{YA}_{\mathrm{i}}+\mathrm{FA}+\mathrm{OA}\right) \\
& 13 \\
& 43 \%\left(\sum_{\mathrm{i}=1} \mathrm{YA}_{\mathrm{i}}+\mathrm{FA}+\mathrm{OA}\right) \leq\left(\mathrm{YA}_{11}+\mathrm{YA}_{12}+\mathrm{YA}_{13}\right) \leq 68 \%\left(\sum_{\mathrm{i}=1} \mathrm{YA}_{\mathrm{i}}+\mathrm{FA}+\mathrm{OA}\right)
\end{aligned}
$$

12. Bills Purchased \& discounted

$\%\left(\mathrm{YA}_{11}+\mathrm{YA}_{12}+\mathrm{YA}_{13}\right) \leq\left(\mathrm{YA}_{11}\right)$

$5 \%\left(\mathrm{YA}_{11}+\mathrm{YA}_{12}+\mathrm{YA}_{13}\right) \leq\left(\mathrm{YA}_{11}\right)$

13. Cash Credit, Overdrafts, Loans repayable on demand $42 \%\left(\mathrm{YA}_{11}+\mathrm{YA}_{12}+\mathrm{YA}_{13}\right) \leq\left(\mathrm{YA}_{12}\right)$

14. Term Loans

$$
\begin{aligned}
& \%\left(\mathrm{YA}_{11}+\mathrm{YA}_{12}+\mathrm{YA}_{13}\right) \leq\left(\mathrm{YA}_{13}\right) \\
& 53 \%\left(\mathrm{YA}_{11}+\mathrm{YA}_{12}+\mathrm{YA}_{13}\right) \leq\left(\mathrm{YA}_{13}\right)
\end{aligned}
$$

15. Fixed Assets

$$
\mathrm{FA}=0.01\left(\sum_{\mathrm{i}=1} \mathrm{YA}_{\mathrm{i}}+\mathrm{FA}+\mathrm{OA}\right)
$$

16. Other Assets

$$
\begin{aligned}
& \%\left(\sum_{\mathrm{i}=1} \mathrm{YA}_{\mathrm{i}}+\mathrm{FA}+\mathrm{OA}\right) \geq(\mathrm{OA}) \\
& 13 \%\left(\sum_{\mathrm{i}=1} \mathrm{YA}_{\mathrm{i}}+\mathrm{FA}+\mathrm{OA}\right) \geq(\mathrm{OA})
\end{aligned}
$$

17. Deposits

$$
\begin{aligned}
& \%\left(\sum_{\mathrm{i}=1} \mathrm{YA}_{\mathrm{i}}+\mathrm{FA}+\mathrm{OA}\right) \leq\left(\mathrm{XL}_{3}+\mathrm{XL}_{4}+\mathrm{XL}_{5}\right) \\
& 85 \%\left(\sum_{\mathrm{i}=1} \mathrm{YA}_{\mathrm{i}}+\mathrm{FA}+\mathrm{OA}\right) \leq\left(\mathrm{XL}_{3}+\mathrm{XL}_{4}+\mathrm{XL}_{5}\right)
\end{aligned}
$$

18. Demand Deposit

$6.4 \%($ XL3 + XL4 + XL5) $\leq($ XL3)

19. Saving Deposit

$$
\begin{aligned}
& \%\left(\mathrm{XL}_{3}+\mathrm{XL}_{4}+\mathrm{XL}_{5}\right) \leq\left(\mathrm{XL}_{4}\right) \\
& 16 \%\left(\mathrm{XL}_{3}+\mathrm{XL}_{4}+\mathrm{XL}_{5}\right) \leq\left(\mathrm{XL}_{4}\right)
\end{aligned}
$$


20. Term Deposit

$\%\left(\mathrm{XL}_{3}+\mathrm{XL}_{4}+\mathrm{XL}_{5}\right) \leq\left(\mathrm{XL}_{5}\right)$

$71 \%\left(\mathrm{XL}_{3}+\mathrm{XL}_{4}+\mathrm{XL}_{5}\right) \leq\left(\mathrm{XL}_{5}\right)$

21. Borrowing Limits

$$
\begin{aligned}
& \%\left(\sum_{\mathrm{i}=1}^{13} \mathrm{YA}_{\mathrm{i}}+\mathrm{FA}+\mathrm{OA}\right) \leq\left(\mathrm{XL}_{6}+\mathrm{XL}_{7}+\mathrm{XL}_{8}\right) \\
& 5 \%\left(\sum_{\mathrm{i}=1} \mathrm{YA}_{\mathrm{i}}+\mathrm{FA}+\mathrm{OA}\right) \leq\left(\mathrm{XL}_{6}+\mathrm{XL}_{7}+\mathrm{XL}_{8}\right)
\end{aligned}
$$

22. Borrowings from RBI

$$
\begin{aligned}
& \left(\mathrm{XL}_{6}\right) \geq \%\left(\mathrm{XL}_{6}+\mathrm{XL}_{7}+\mathrm{XL}_{8}\right) \\
& \left(\mathrm{XL}_{6}\right) \geq 13 \%\left(\mathrm{XL}_{6}+\mathrm{XL}_{7}+\mathrm{XL}_{8}\right)
\end{aligned}
$$

23. Borrowings from Banks And other institutions \& Agencies

$$
\begin{aligned}
& \%\left(\mathrm{XL}_{6}+\mathrm{XL}_{7}+\mathrm{XL}_{8}\right) \leq\left(\mathrm{XL}_{7}\right) \\
& 62 \%\left(\mathrm{XL}_{6}+\mathrm{XL}_{7}+\mathrm{XL}_{8}\right) \leq\left(\mathrm{XL}_{7}\right)
\end{aligned}
$$

24. Borrowings outside India

$$
\begin{aligned}
& \%\left(\mathrm{XL}_{6}+\mathrm{XL}_{7}+\mathrm{XL}_{8}\right) \leq\left(\mathrm{XL}_{8}\right) \\
& 24 \%\left(\mathrm{XL}_{6}+\mathrm{XL}_{7}+\mathrm{XL}_{8}\right) \leq\left(\mathrm{XL}_{8}\right)
\end{aligned}
$$

25. Other liabilities

$$
\begin{aligned}
& \%\left(\sum_{\mathrm{i}=1} \mathrm{YA}_{\mathrm{i}}+\mathrm{FA}+\mathrm{OA}\right) \leq\left(\mathrm{XL}_{9}\right) \\
& 0.9 \%\left(\sum_{\mathrm{i}=1} \mathrm{YA}_{\mathrm{i}}+\mathrm{FA}+\mathrm{OA}\right) \leq\left(\mathrm{XL}_{9}\right)
\end{aligned}
$$

26. Provisions

$$
\begin{aligned}
& \%\left(\sum_{\mathrm{i}=1}^{13} \mathrm{YA}_{\mathrm{i}}+\mathrm{FA}+\mathrm{OA}\right) \leq\left(\mathrm{XL}_{10}\right) \\
& 1.7 \%\left(\sum_{\mathrm{i}=1} \mathrm{YA}_{\mathrm{i}}+\mathrm{FA}+\mathrm{OA}\right) \leq\left(\mathrm{XL}_{10}\right)
\end{aligned}
$$

\section{Decision/Goal Constraints}

1. Market Share of Credit

$\mathrm{YA}_{11}+\mathrm{YA}_{12}+\mathrm{YA}_{13}+\mathrm{d}_{1}{ }^{-}-\mathrm{d}_{1}{ }^{+}=0.0164 *(97674300000)$

2. Market Share of Deposit

$\mathrm{XL}_{3}+\mathrm{XL}_{4}+\mathrm{XL}_{5}+\mathrm{d}_{2}^{-}-\mathrm{d}_{2}^{+}=0.017 *(125725860000)$

3. Return on Asset

$$
0.004 *\left(\sum_{\mathrm{i}=1}^{13} \mathrm{YA}_{\mathrm{i}}+\mathrm{FA}+\mathrm{OA}\right)+\mathrm{d}_{3}{ }^{-}-\mathrm{d}_{3}{ }^{+}=\text {Net Profit }
$$


4. Return on equity

$0.065^{*}\left(\mathrm{XL}_{1}+\mathrm{XL}_{2}\right)+\mathrm{d}_{4}{ }^{-}-\mathrm{d}_{4}{ }^{+}=$Net Profit

5. Capital adequacy ratio

$$
\begin{gathered}
\mathrm{XL}_{1}+\mathrm{XL}_{2}+\mathrm{d}_{5}^{-}-\mathrm{d}_{5}^{+}=0.116^{*}\left(0^{*}\left(\mathrm{YA}_{1}+\mathrm{YA}_{2}\right)+0.2^{*}\left(\mathrm{YA}_{3}+\mathrm{YA}_{4}\right)+0 *\left(\mathrm{YA}_{5}+\mathrm{YA}_{6}\right)+1.25^{*}(\right. \\
\left.\left.\mathrm{YA}_{7}\right)+1 *\left(\mathrm{YA}_{8}+\mathrm{YA}_{9}+\mathrm{YA}_{10}\right)+0.2^{*}\left(\mathrm{YA}_{11}+\mathrm{YA}_{12}\right)+1.25^{*} \mathrm{YA}_{13}+1 * \mathrm{FA}\right)
\end{gathered}
$$

6. Liquidity risk- (liquidity coverage ratio)

HQLA $+\mathrm{d}_{6}{ }^{-}-\mathrm{d}_{6}{ }^{+}=224670000$

7. Net NPA

$\mathrm{NPA}+\mathrm{d}_{7}^{-}-\mathrm{d}_{7}^{+}=0.0465^{*}\left(\mathrm{YA}_{11} \mathrm{YA}_{12}+\mathrm{YA}_{13}\right)$

The model analysed the asset and liabilities of Allahabad bank for the year 2019. The target value shows the most optimum level of the bank. After simulating the model, the most optimum solution is presented for the bank. In the market share of credit, the target is set at $1.64 \%$ of the aggregate market share of the credit of scheduled commercial banks. Likewise, the market share of the deposit is set at $1.7 \%$, return on asset is $0.4 \%$, return on equity is $6.5 \%$, capital adequacy ratio is set at $11.6 \%$, cash flow for 30 days has been taken from the 2019 annual report as 224670000 (figure in '000), and NPA is $4.65 \%$.

The total assets have been taken from the balance sheet of 2019 as 2485757709 (figure in '000), and capital is taken as 20968358 (figure in '000), an assumption that the bank does not increase its equity every year.

In model,

Net Profit $=\left(0.012 *\left(\mathrm{YA}_{3}+\mathrm{YA}_{4}\right)+\% *\left(\mathrm{YA}_{5}+\mathrm{YA}_{6}+\mathrm{YA}_{7}+\mathrm{YA}_{8}+\mathrm{YA}_{9}+\mathrm{YA}_{10}+\mathrm{YA}_{11}+\mathrm{YA}_{12}+\mathrm{YA}_{13}\right)\right.$ $+0.009 * \mathrm{TA})-(\% *(\mathrm{XL3}+\mathrm{XL} 4+\mathrm{XL} 5+\mathrm{XL6}+\mathrm{XL7}+\mathrm{XL})+0.014 * \mathrm{TA}+0.017 *(\mathrm{YA} 5+\mathrm{YA} 6+\mathrm{YA} 7$ $+\mathrm{YA} 8+\mathrm{YA} 9+\mathrm{YA} 10+\mathrm{YA} 11+\mathrm{YA} 12+\mathrm{YA} 13+\mathrm{FA}))$

Interest income on money at call and short notice is $1.2 \%$ taken fixed for the banks after analyzing the interest income of banks with respect to money at call and short notice assuming balance with RBI are only sufficient to satisfy CRR requirement. There is no interest paid by RBI on such a cash balance. The interest income on investments and advances is taken as $7.61 \%$ after considering the average yield of Allahabad bank in 2019. Other income is taken as $0.9 \%$ of total assets fixed for all banks. The interest expense on deposits and borrowing is 5.03\%, taken from the average cost of the fund in the 2019 annual report of Allahabad bank. The other expenses are recorded at 1.4\% of the total asset for the banks, and provisions are $1.7 \%$ of total fixed assets, advances, and investments. It is to be noted that all the figures are in ' 000 .

\section{RESULTS AND ANALYSIS}

The results of the model are compared with actual figures of the balance sheet for the year 2019. Table 3 highlights any deviation in model value from an actual value. Optimized assets and liabilities of Allahabad bank have been calculated, which shows that the bank can reallocate its assets and liabilities and achieve more than its current position. In 2019, CRR was 4\%, SLR was $19.5 \%$, PSL was $40 \%$ and CAR was $11.5 \%$ (taken $11.6 \%$ in model). As already mentioned, after testing the model for sensitivity, the targets at which bank is most optimal are used. 
Table 3. Real and Model Values Assets of Allahabad Bank

\begin{tabular}{|l|l|l|l|l|}
\hline Allahabad Bank & & Real & Model & Deviation \\
\hline Assets & & & & \\
\hline Cash and Bank & YA1 \& YA2 & 96723216 & 111859100 & -15135884 \\
\hline Money at Call & YA3 \& YA4 & 45611942 & 26312780 & 19299162 \\
\hline SLR Investment & YA5 \& YA6 YA9, & 104655971 & 103407500 & 1248471 \\
\hline $\begin{array}{l}\text { Non SLR Investment Purchased and } \\
\text { Advances }\end{array}$ & $\begin{array}{l}\text { YA7, YA11 } \\
\text { YA11, YA12, YA13 }\end{array}$ & $\begin{array}{l}142212163 \\
0\end{array}$ & 1601858530 & -179736900 \\
\hline $\begin{array}{l}\text { Bills Repayable on } \\
\text { Discounted } \\
\text { Lash Credits, Overdrafts and } \\
\text { Demand }\end{array}$ & YA12 & 5238163 & 80092930 & -74854767 \\
\hline Term Loans & YA13 & 652786810 & 672780600 & -19993790 \\
\hline Fixed Asset & FA & 764096657 & 848985000 & -84888343 \\
\hline Other Assets & OA & 35382578 & 24857580 & 10524998 \\
\hline \begin{tabular}{l} 
Total Asset \\
\hline
\end{tabular} & 90339210 & 74573060 & 15766150 \\
\hline
\end{tabular}

Table 4. Real and Model Values Liabilities of Allahabad Bank

\begin{tabular}{|c|c|c|c|c|}
\hline $\begin{array}{l}\text { Allahabad } \\
\text { Bank }\end{array}$ & & Real & Model & Deviation \\
\hline $\begin{array}{l}\text { Capital } \\
\text { Reserves }\end{array}$ & XL1 \& XL2 & 91303177 & 156058660 & -64755483 \\
\hline Demand Deposit & XL3 & 119864594 & 136789700 & -16925106 \\
\hline Saving Deposit & XL4 & 940837537 & 341974300 & 598863237 \\
\hline Term Deposit & XL5 & 1082638544 & 1658576000 & -575937456 \\
\hline $\begin{array}{l}\text { Borrowing in } \\
\text { India }\end{array}$ & XL6, XL7 & 93769660 & 94458800 & -689140 \\
\hline $\begin{array}{l}\text { Borrowing } \\
\text { Outside India }\end{array}$ & XL8 & 31119750 & 29829090 & 1290660 \\
\hline Other Liabilities & XL9 & 9529382 & 22371820 & -12842438 \\
\hline Provisions & XL10 & 47735065 & 45699680 & 2035385 \\
\hline $\begin{array}{l}\text { Share } \\
\text { Application }\end{array}$ & & 68960000 & 0 & 68960000 \\
\hline Total Liabilities & & 2485757709 & 2485758050 & -341 \\
\hline
\end{tabular}

The model is then run-on Lingo software, and the results are given in table 3 and table 4 . In table 3 and 4, deviation in assets and liabilities from real value in Balance Sheet of Allahabad Bank is 
presented. It depicts the required asset liability mix for the bank. Major deviations are noticed in investments, advances, saving deposits, demand deposits, and term deposits.

Table 5. Analysis of Allahabad bank

\begin{tabular}{|l|l|}
\hline & Model Values \\
\hline CRR \% & $5 \%$ \\
\hline SLR \% & $25 \%$ \\
\hline NTDL & 2238152000 \\
\hline HQLA & 224670000 \\
\hline Net Profit & 6570514 \\
\hline Return on Asset \% & 0.264 \\
\hline Return On equity \% & 4.21 \\
\hline Liquid asset & 565222500 \\
\hline Market Share of credit & $1.64 \%$ \\
\hline Market Share of deposit & $1.70 \%$ \\
\hline Capital Adequacy ratio & $11.60 \%$ \\
\hline Risk Weighted Asset & 1345334000 \\
\hline CD Ratio & $75 \%$ \\
\hline Liquidity coverage ratio \% & $100 \%$ \\
\hline Priority lending ratio & $40 \%$ \\
\hline NPA & $4.65 \%$ \\
\hline
\end{tabular}

Table 5 shows that the model has satisfied all the statutory constraints and decision constraints. The CRR achieved here is 5\%, and SLR is $25 \%$. The credit in priority sector lending is $40 \%$. The total asset is also equal to the total liability. In the model, the total asset's value was kept the same as real total assets in 2019, so that there is a much better comparison. The model has successfully achieved all seven goals, although there are few deviations recorded. There is no infeasibility in the solution. The objective is to minimize the deviations that negatively affect the bank's performance. The actual market share of the credit of Allahabad bank is $1.45 \%$ in 2019, whereas the model has achieved $1.64 \%$. It shows that the bank can increase its market share of credit to reach the optimization level. The actual market share of deposits for Allahabad bank is $1.7 \%$, and in the model, the market share of the deposit is $1.7 \%$. It shows that the bank doesn't need any change in the market share of the deposit. It is already having an optimum market share of deposits. The credit deposit (CD ratio) achieved is 75\%, as against $66.3 \%$. The bank generates a $0.264 \%$ return on the asset in the model, which is better than the actual value, i.e., $-3.35 \%$. However, the targeted return on assets is $0.4 \%$. The model reports a positive deviation of 3372517 , which shows that to achieve a return on the asset at $0.4 \%$, the bank has to 
increase its profit by 3372517. However, with given resources and constraints, it is not possible to optimize the model further.

The model wants the bank to achieve a $6.5 \%$ return on equity. However, it has achieved $4.21 \%$. There is a positive deviation of 3573302, which represents that the bank has to increase its profit by the specified amount to report a $6.5 \%$ return on equity. However, the return on equity is $4.23 \%$, as against 91.27\% reported by Allahabad bank in 2019. In the year 2019 bank has suffered a loss of (83339612), while as per the model, the net profit is 6570514 . In the model, the bank has a capital adequacy ratio of $11.6 \%$, as targeted. The liquidity coverage ratio is $100 \%$, which shows that the bank has sufficient highquality liquid asset to match the cash outflows for 30 days. The model also shows that the liquidity asset to total asset ratio is $22.73 \%$, and a liquid asset to total deposit is $26.44 \%$. The bank has enough liquid assets to protect itself from a liquidity crisis. The NPA ratio is computed by dividing net NPAs by Net Advances. There is a negative deviation in NPA of 347421.2. The model is increasing NPA from 74139000 to 74486421.2 as there is an increase in advances. The motive is to see whether the model is able to limit the NPAs. The model has an NPA ratio of $4.65 \%$ against the actual NPA ratio of Allahabad bank recorded as 5.22\% in the annual report of 2019.

Table 6. The deviation from the targets

\begin{tabular}{|l|l|l|}
\hline GOALS & Negative deviation & Positive deviation \\
\hline Market Share of the credit & 0 & 0 \\
\hline Market Share of the deposit & 0 & 0 \\
\hline Return on Asset & 0 & 3372517 \\
\hline Return On equity & 0 & 3573302 \\
\hline Capital Adequacy ratio & 0 & 0 \\
\hline Liquidity coverage ratio \% & 0 & 0 \\
\hline NPA & 347421.2 & 0 \\
\hline
\end{tabular}

Table 6 shows the under and overachievement of targets. The negative deviation and positive deviation are recorded. The model wants to minimize the underachievement of targets, and it has been achieved. In Goal Programming, when underachievement of any goal is to be minimized, then the objective function undertakes negative deviation ( $\mathrm{D}$ minus). On the other hand, if overachievement of goal is to be minimized, then positive deviation is undertaken in the objective function. In this model, we want to minimize the underachievement of market share of credit, market share of the deposit, return on asset, return on equity, capital adequacy ratio, and liquidity risk, whereas we want to minimize the overachievement of NPA, i.e., we don't want to increase NPA. As can be seen from Table 5 , all the goals are not $100 \%$ achieved. Few goals have shortages or excess from the targeted value. 
Table 7. Interest on asset and liability effect on profitability of Allahabad Bank

\begin{tabular}{|c|c|c|c|c|c|c|c|c|c|c|c|c|}
\hline \multirow{21}{*}{ 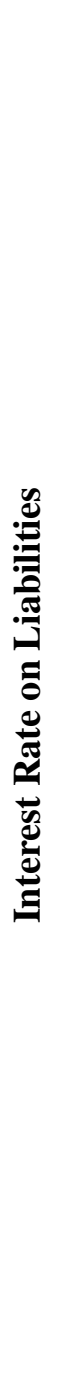 } & \multicolumn{12}{|c|}{ Interest Rate on Asset } \\
\hline & & 0.07 & 0.071 & 0.072 & 0.073 & 0.074 & 0.075 & 0.08 & 0.077 & 0.078 & 0.079 & 0.08 \\
\hline & 0.04 & 161.5 & 184 & 206.5 & 229 & 251.4 & 273.9 & 296 & 318.9 & 341.4 & 363.9 & 386 \\
\hline & 0.041 & 138.9 & 161.4 & 183.9 & 206.3 & 228.8 & 251.3 & 274 & 296.3 & 318.8 & 341.2 & 364 \\
\hline & 0.042 & 116.2 & 138.8 & 161.3 & 183.7 & 206.2 & 228.7 & 251 & 273.7 & 296.1 & 318.6 & 341 \\
\hline & 0.043 & 93.67 & 116.2 & 138.6 & 161.1 & 183.6 & 206.1 & 229 & 251 & 273.5 & 296 & 318 \\
\hline & 0.044 & 71.05 & 93.53 & 116 & 138.5 & 161 & 183.5 & 206 & 228.4 & 250.9 & 273.4 & 296 \\
\hline & $\mathbf{0 . 0 4 5}$ & 48.43 & 70.92 & 93.4 & 115.9 & 138.4 & 160.8 & 183 & 205.8 & 228.3 & 250.8 & 273 \\
\hline & 0.046 & 25.82 & 48.3 & 70.78 & 93.26 & 115.7 & 138.2 & 161 & 183.2 & 205.7 & 228.2 & 251 \\
\hline & 0.047 & 3.2 & 25.68 & 48.16 & 70.65 & 93.13 & 115.6 & 138 & 160.6 & 183.1 & 205.5 & 228 \\
\hline & 0.048 & -19.4 & 3.07 & 25.55 & 48.03 & 70.51 & 92.99 & 115 & 138 & 160.4 & 182.9 & 205 \\
\hline & 0.049 & -42 & -19.6 & 2.93 & 25.41 & 47.89 & 70.38 & 92.9 & 115.3 & 137.8 & 160.3 & 183 \\
\hline & 0.05 & -64.6 & -42.2 & -19.7 & 2.8 & 25.28 & 47.76 & 70.2 & 92.72 & 115.2 & 137.7 & 160 \\
\hline & 0.051 & -87.2 & -64.8 & -42.3 & -19.8 & 2.66 & 25.14 & 47.6 & 70.11 & 92.59 & 115.1 & 138 \\
\hline & 0.052 & -109 & -87.4 & -64.9 & -42.4 & -20 & 2.53 & 25 & 47.49 & 69.97 & 92.45 & 115 \\
\hline & $\mathbf{0 . 0 5 3}$ & -132 & -110 & -87.5 & -65.1 & -42.6 & -20.1 & 2.39 & 24.87 & 47.36 & 69.84 & 92.3 \\
\hline & 0.054 & -155 & -133 & -110 & -87.7 & -65.2 & -42.7 & -20.2 & 2.26 & 24.74 & 47.22 & 69.7 \\
\hline & 0.055 & -177 & -155 & -133 & -110 & -87.8 & -65.3 & -42.8 & -20.36 & 2.12 & 24.6 & 47.1 \\
\hline & 0.056 & -200 & -178 & -155 & -133 & -110 & -87.9 & -65.5 & -42.97 & -20.49 & 1.99 & 24.5 \\
\hline & 0.057 & -223 & -200 & -178 & -156 & -133 & -111 & -88.1 & -65.59 & -43.11 & -20.6 & 1.85 \\
\hline & 0.058 & -245 & -223 & -201 & -178 & -156 & -133 & -111 & -88.21 & -65.73 & -43.2 & -20.8 \\
\hline
\end{tabular}

The sensitivity test of net profit with change in the interest rate of advances and investment with change in the interest rate of deposits and borrowing is shown in table 7. It shows that keeping every other element constant, a slight change in interest rate can affect the net profit of the bank drastically. The sensitivity test reveals that the bank is profitable at a $7 \%$ interest rate on advances and investment till $4.7 \%$ interest rate of deposits and borrowing. If the bank is able to generate Net interest margin (NII) of $2.30 \%$, it can be profitable. However, at $2.1 \%$ NII also, the bank is profitable when the interest rate on advances and investment is $8.6 \%$ and interest rate on deposit and borrowing is $6.3 \%$ interest expense. As interest rate on deposits and borrowing increase bank is generating losses. With an increase in interest, the expense bank has to increase its interest income to remain profitable. 
Table 8. Credit-Deposit effect on profitability of Allahabad Bank (fig '00000000)

\begin{tabular}{|c|c|c|c|c|c|c|c|c|c|c|c|c|}
\hline & \multicolumn{12}{|c|}{ Advances } \\
\hline & & 15000 & 15200 & 15400 & 15600 & 15800 & 16000 & 16019 & 16200 & 16400 & 16600 & 16800 \\
\hline \multirow{12}{*}{ 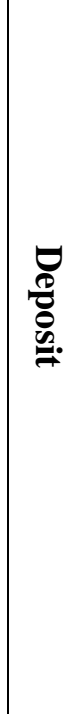 } & 19000 & 107.6 & 122.8 & 138 & 153.2 & 168.5 & 183.7 & 185.1 & 198.9 & 214.1 & 229.3 & 244.6 \\
\hline & 19500 & 82.42 & 97.64 & 112.9 & 128.1 & 143.3 & 158.5 & 159.9 & 173.7 & 189 & 204.2 & 219.4 \\
\hline & 20000 & 57.27 & 72.49 & 87.71 & 102.9 & 118.2 & 133.4 & 134.8 & 148.6 & 163.8 & 179 & 194.3 \\
\hline & 20500 & 32.12 & 47.34 & 62.56 & 77.78 & 93 & 108.2 & 109.6 & 123.4 & 138.7 & 153.9 & 169.1 \\
\hline & 21000 & 6.97 & 22.19 & 37.41 & 52.63 & 67.85 & 83.07 & 84.49 & 98.29 & 113.5 & 128.7 & 144 \\
\hline & 21373 & -11.8 & 3.41 & 18.63 & 33.85 & 49.07 & 64.29 & 65.7 & 79.51 & 94.73 & 110 & 125.2 \\
\hline & 21500 & -18.2 & -2.96 & 12.26 & 27.48 & 42.7 & 57.92 & 59.34 & 73.14 & 88.36 & 103.6 & 118.8 \\
\hline & 22000 & -43.3 & -28.11 & -12.9 & 2.33 & 17.55 & 32.77 & 34.19 & 47.99 & 63.21 & 78.43 & 93.65 \\
\hline & 22500 & -68.5 & -53.26 & -38 & -22.8 & -7.6 & 7.62 & 9.04 & 22.84 & 38.06 & 53.28 & 68.5 \\
\hline & 23000 & -93.6 & -78.41 & -63.2 & -48 & -32.8 & -17.5 & -16.11 & -2.31 & 12.91 & 28.13 & 43.35 \\
\hline & 23500 & -119 & -103.6 & -88.3 & -73.1 & -57.9 & -42.7 & -41.26 & -27.5 & -12.2 & 2.98 & 18.2 \\
\hline & 24000 & -144 & -128.7 & -113 & \begin{tabular}{|l|}
-98.3 \\
\end{tabular} & $\begin{array}{l}-83.1 \\
\end{array}$ & $\begin{array}{l}-67.8 \\
\end{array}$ & -66.41 & -52.6 & -37.4 & -22.2 & -6.95 \\
\hline
\end{tabular}

Another table 8 shows the sensitivity analysis of credit and deposits. When all other elements are constant, how a change in advances and deposit affect the profitability is reflected in table 8 . The bank is profitable if the Credit-Deposit ratio is above 70.6\%. As per the 2019 annual report, Allahabad bank has a $66.3 \% \mathrm{CR}$ ratio; therefore, it is incurring heavy losses. Ideally, the maximum $\mathrm{CD}$ ratio should be $75 \%$ or so. Therefore, a CD ratio between $70.6 \%$ to $75 \%$ is profitable and feasible. The sensitivity analysis of the model is the best advantage of goal programming. It is possible to modify variables to determine their effect on the optimal solution.

The model has been tested for sensitivity so that there are the least deviations in the solution and, wherever possible, minimize deviation to 0 . Any change in the constraint may lead to a solution where deviations from the target may arise. It is an integral part of the solution to test the effect of parameters for sensitivity. There are high chances of frequent change in goals, priorities, and available resources in the real world. Any change will result in the alteration of the optimum solution (Lee, 1981).

\section{FINDINGS}

Goal Programming is a widely used technique in multi-criteria decision-making problems (Romero et al., 1998). It is a well-defined analytical approach to an ill-defined optimization problem (Rosenthal, 1983). It is a simple to understand, straightforward and effective method that can be used even by managers. It is easy to use in complex problems with a wide range of decision variables, objectives, and constraints. In the GP model, multiple conflicting goals that cannot be fully satisfied are handled effectively. It can be used in a variety of fields, for example, agriculture, transportation, warehousing, capital budgeting, engineering, portfolio selection, loan management, asset management, finance, and economics, etc.

The model generates a feasible optimum solution. The deviations show that all goals are not entirely attainable due to limited resources. The results of the model assert that the GP technique is able to develop the asset and liability mix that fulfills the goals and constraints. It is found that Allahabad 
bank can deploy more resources to maximize returns if it can increase its market share of the credit. If a bank has an opportunity to market its share of credit from $1.45 \%$ to $1.64 \%$, it can create more revenue and achieve higher profitability. There is a possibility for the bank to restructure its assets and liabilities. A reduction in money at call with other banks and SLR investment, whereas an increase in short-term and long-term credit, will accelerate the income-earning capacity of the bank. It can also increase demand deposits as they are low-cost funds for banks. The optimum utilization of fixed and current assets can also increase the efficiency of the bank (Seth et al., 2020; Tanwar et al., 2020). This model shows the deviations that pinpoint the asset and liabilities that need attention. It helps management to change its strategies accordingly.

This model is flexible enough to incorporate changes in goals and constraints. Banks' managers can use it for forecasting. The goals/targets can be set, and based on constraints, it can be determined to what extent such targets can be achieved, overachieved, or underachieved. Management can use it as a tool for planning, forecasting, and budgeting. The results can be used for changing strategies and developing policies within the bank for a better financial position in the future.

\section{LIMITATIONS}

Even though goal programming sounds promising and useful, yet it has been criticized by many authors for setting weights or priority for goals. However, few authors suggested the use of the Analytical Hierarchy Process (AHP) or other interactive methods for assigning weights and priority. In preemptive goal programming, the model disallows even the slightest trade-off of deviations in higher ranking. It is possible that some loss in higher priority goals may lead to maximization of overall objectives. The construction of the model is time-consuming, especially where there is a high number of variables and constraints.

The multipliers in management constraints are difficult to determine due to the dynamic nature of banking. There is no set the trend in banking that can be derived from secondary data for assigning multipliers. The risk weight of assets is complex due to the varied nature of assets. The model only provides estimation. The volatility of the interest rate has not been considered. As each asset and liability have a different rate of interest, it is difficult to incorporate the same in the model.

\section{CONCLUSION}

Banks' focus shifted on both assets and liabilities after the shortfall of funds and volatility in interest rates. RBI issued guidelines for Asset Liability Management which has become a primary concern in the financial environment. This study reflects the optimization of assets and liability of banks in India using the case of Allahabad bank. The restructuring of assets and liabilities in the balance sheet to optimize profitability is achieved using goal programming. Multi-objectives of banks have been fulfilled, and deviation from the objective is recorded. The goals that have more weight are fulfilled first to minimize deviation. The study reflects the scope for improvement in the bank by judiciously using its resources.

\section{REFERENCES}

Adebisi, A. J., Alabi, A. W., \& Fatimehin, K. (2020). Influence Of Risk Assets Impairment On Performance Of Nigerian Listed Deposit Money Banks. International Journal of Accounting \& Finance Review, 5(3), 41-63.

Chakroun, F., \& Abid, F. (2013). A Multiobjective Model for Bank Asset Liability Management: The Case of a Tunisian Bank. The IUP Journal of Financial Risk Management, 10(4), 35-56. 
https://doi.org/10.2139/ssrn.2246972

Chambers, D., \& Charnes, A. (1961). Inter-Temporal Analysis and Optimization of Bank Portfolios. Management Science, 7(4), 393-410. https://doi.org/10.1287/mnsc.7.4.393

Charnes, A., \& Cooper, W. W. (1977). Goal programming and multiple objective optimizations: Part 1. European Journal of Operational Research, 1(1), 39-54. https://doi.org/https://doi.org/10.1016/S0377-2217(77)81007-2

Chaturvedi, V. (2014). Asset Liability Management in Banks. International Journal of Engineering Technology, Management and Applied Sciences, 1(2), 2349-4476. Retrieved from http://www.ijetmas.com/admin/resources/project/paper/f201406281403951723.pdf

Cohen, K. J., \& Hammer, F. S. (1967). Linear Programming and Optimal Bank Asset Management Decisions. The Journal of Finance, 22(2), 147-165. https://doi.org/10.2307/2325551

Dash, M., \& Pathak, R. (2011). A Linear Programming Model for Assessing Asset- Liability Management in Banks. The IUP Journal of Financial Risk Management : IJFRM, 8(1), 50-67.

Eatman, J., \& Sealey, C. (1979). A multiobjective linear programming model for commercial bank balance sheet management. Journal of Bank Research, 9, 227-236.

Fabozzi, F. J., \& Konishi, A. (1991). Asset/liability Management: Investment Strategies, Liquidity Requirements, and Risk Controls for Banks and Thrifts. Probus Publishing Company.

Fielitz, B. D., \& Loeffler, T. A. (1979). A Linear Programming Model for Commercial Bank Liquidity Management. Financial Management, 8(3), 41-50.

Fortson, J. C., \& Dince, R. R. (1977). An Application of Goal Programming to Management of a Country Bank. Journal of Bank Research, Winter, 311-319.

Giokas. D, \& Vassiloglou, M. (1991). A goal programming model for bank assets and liabilities management. European Journal of Operational Research, 50(1), 48-60. https://doi.org/https://doi.org/10.1016/0377-2217(91)90038-W

Greuning, H. V., \& Bratanovic, S. B. (2009). Analyzing Banking Risk: A framework for assessing corporate governance and finacial risk management. In Analyzing Banking Risk A framework for assessing corporate governance and finacial risk management (Third). The World Bank. Retrieved from http://books.google.com/books?id=73CX808akZ4C\&pgis=1

Haddad, A., Ammari, A. El, \& Bouri, A. (2019). Impact of the Ownership Structure on the Financial Performance of Banks: Comparative Study between Conventional and Islamic Banks. International Journal of Accounting \& Finance Review, 4(2), 50-63. https://doi.org/10.46281/ijafr.v4i2.442

Halim, B. A., Karim, H. A., Fahami, N. A., Mahad, N. F., Nordin, S. K. S., \& Hassan, N. (2015). Bank 
Financial Statement Management Using A Goal Programming Model. Procedia - Social and Behavioral Sciences, 211(November), 498-504. https://doi.org/10.1016/j.sbspro.2015.11.066

Ignizio, J. P. (1981). Linear Programming in Single and Multiple Objective Systems. Prentice-Hall International Series in Industrial \& Systems Engineering).

Jain, M. K., Dalela, A. K., \& Tiwari, S. K. (2010). Application of Fuzzy Mathematical Model in Assets-Liabilities. International Journal of Trade, Economics and Finance, 1(3), 247-253. https://doi.org/10.7763/ijtef.2010.v1.45

Jayanthi, M., \& Umarani, R. (2014). Asset-Liability Management in Banks. CKPIM Business Review, 9(2), 10-25.

Joshi, S. P., \& Sontakay, R. V. (2017). Review Paper on Asset Liability Management in Banking System. Imperial Journal of Interdisciplinary Research, 3(6), 670-678.

Kalyan, N. B. (2017). Banking Sector Reforms in India. International Journal of Management and Humanities, 4(4), 13-18. https://doi.org/10.2139/ssrn.2303731

Kosmidou, K., \& Zopounidis, C. (2002). An optimization scenario methodology for bank asset liability management. Operational Research, 2(2), 279-287. https://doi.org/http://dx.doi.org/10.1007/BF02936331

Kosmidou, K., \& Zopounidis, C. (2004a). Combining Goal Programming Model With Simulation Analysis For Bank Asset Liability Management. INFOR: Information Systems and Operational Research, 42(3), 175-187.

Kosmidou, K., \& Zopounidis, C. (2004b). Goal Programming Techniques for Bank Asset Liability Management (90th ed.). Kluwer Academic Publishers Boston. https://doi.org/10.1007/b106009

Kruger, M. (2011). A Goal Programming Approach to Strategic Bank Balance Sheet Management. SAS Global Forum 2011 Banking, Financal Services and Insurance, 1-11.

Lee, S. M. (1981). Goal Programming. In A. G. Holzman (Ed.), Mathematical Programming for Operations Researchers and Computer Scientists. Marcel Dekker Inc.

Matz, L., \& Neu, P. (Eds.). (2007). Liquidity Risk Measurement and Management: A practitioner's guide to global best practices. John Wliey \& Sons Pte Ltd.

Naderi, S., Minouei, M., \& Gashti, H. P. (2013). Asset and Liability Optimal Management Mathematical Modeling for Bank. Journal of Basic and Applied Scientific Research, 3(1), 484493.

Professional Actuarial Specialty Guide: Asset- Liability Management. (2003). Society of Actuaries (SOA). Retrieved from www.soa.org/library/professional-actuarial-specialtyguides/professional-actuarial-specialty-guides/2003/september/spg0308alm.pdf 
RBI. (1999). Asset - Liability Management ( ALM ) System. Reserve Bank of India Notifications, 123. Retrieved from https://rbidocs.rbi.org.in/rdocs/notification/PDFs/5212.pdf

Riyazahmed, K., \& Baranwal, G. (2021). Determinants of Credit Risk. International Journal of Accounting \& Finance Review, 6(1), 53-71. https://doi.org/10.46281/ijafr.v6i1.1005

Romero, C., Tamiz, M., \& Jones, D. (1998). Goal programming, compromise programming and reference point method formulations: Linkages and utility interpretations. Journal of the Operational Research Society, 49(9), 986-991.

Rosenthal, R. (1983). Goal programming- A Critique. Nz Oper.Res., 11(1), 1-8. Retrieved from https://www.researchgate.net/publication/256502481_A_Preemptive_Goal_Programming_Mo del_for_the_Sustainability_of_Growth_in_Engineering_Colleges

Saaty, T. L. (2008). Decision making with the Analytic Hierarchy Process. International Journal of Services Sciences, 1(1), 83-98. https://doi.org/10.1504/ijssci.2008.017590

Sedzro, K., Marouane, A., \& Assogbavi, T. (2012). Analytical Hierarchy Process and Goal Programming Approach for Asset Allocation. Journal of Mathematical Finance, 02(01), 96104. https://doi.org/10.4236/jmf.2012.21012

Seth, H., Saurabh, C., \& Sharma, S. (2020). Benchmarking the efficiency model for working capital management: data envelopment analysis approach. International Journal of Productivity and Performance Management, in print.

Singh, A., \& Tandon, P. (2012). Asset - Liabilty Management in Indian Banking Industry. Asia Pacific Journalof Marketing \& Management Review, 1(3), 121-132.

Singh, K. (2013). Asset-Liability Management in Banks: A Dynamic Approach. AIMA Journal of Management \& Research, 7(2), 1-14.

Tanwar, J., Seth, H., Vaish, A. K., \& Rao, N. V. M. (2020). Revisiting the Efficiency of Indian Banking Sector: An Analysis of Comparative Models Through Data Envelopment Analysis. Indian Journal of Finance and Banking, 4(1), 92-108. https://doi.org/10.46281/ijfb.v4i1.585

Tanwar, J., Vaish, A. K., \& Rao, N. V. M. (2020). Mathematical Modeling of Asset Liability Management in Banks Using Goal Programming and Ahp. Indian Journal of Finance and Banking, 4(4), 1-19. https://doi.org/10.46281/ijfb.v4i4.899

Viswanathan, P. K., \& Balasubramanian, G. (2007). Modelling asset allocation for banks- A goal programming approach. Journal of National Institute of Bank Management-Prajnan, $X X X \operatorname{VI}(1), 135-145$.

Viswanathan, P. K., Ranganatham, M., \& Balasubramanian, G. (2014). Modeling asset allocation and liability composition for Indian banks. Managerial Finance, 40(7), 700-723. https://doi.org/10.1108/MF-10-2013-0276 
Zaloom, V., Tolga, A., \& Chu, H. (1986). Bank Fund Management By Goal Programming. Computers \& Industrial Engineering, 11(1-4), 132-135. https://doi.org/https://doi.org/10.1016/03608352(86)90064-1

\section{Copyrights}

Copyright for this article is retained by the author(s), with first publication rights granted to the journal. This is an open-access article distributed under the terms and conditions of the Creative Commons Attribution license (http://creativecommons.org/licenses/by/4.0/) 